\title{
INFLUENCE OF METAL EXPOSURE HISTORY ON THE BIOACCUMULATION AND SUBCELLULAR DISTRIBUTION OF AQUEOUS CADMIUM IN THE INSECT HYDROPSYCHE CALIFORNICA
}

\author{
Daniel J. Cain, * David B. Buchwalter, and Samuel N. Luoma \\ U.S. Geological Survey, 345 Middlefield Road, Menlo Park, California 94025
}

(Received 13 April 2005; Accepted 6 September 2005)

\begin{abstract}
The influence of metal exposure history on rates of aqueous $\mathrm{Cd}$ accumulation, elimination, and subcellular distribution was examined in the aquatic insect Hydropsyche californica. Specimens were obtained from a reference site and a metal-contaminated site and returned to the laboratory where they were continuously exposed to aqueous $\mathrm{Cd}(518 \mathrm{ng} / \mathrm{L}$, nominal) for $6 \mathrm{~d}$, followed by $9 \mathrm{~d}$ of depuration. Rates of Cd accumulation and elimination were similar in insects from the two sites. Efflux rate constants, $k_{e}$, ranged from 0.20 to $0.24 / \mathrm{d}\left(t_{1 / 2} \approx 3 \mathrm{~d}\right)$. Immediately following exposure, the cytosol accounted for $40 \%$ of the body burden in insects from both sites; however, $89 \pm 2 \%$ of the cytosolic Cd was associated with metallothionein-like proteins (MTLP) in insects from the contaminated site, compared to $60 \pm 0 \%$ in insects from the reference site. The concentration of Cd bound to non-MTLPs (representing potentially Cd-sensitive proteins) was significantly greater in the insects from the reference site (134 $\pm 7 \mathrm{ng} / \mathrm{g})$ than in those from the contaminated site $(42 \pm 2 \mathrm{ng} / \mathrm{g})$. At the end of the depuration period, $90 \%$ of the accumulated Cd body burden had been eliminated, and Cd concentrations in MTLPs and non-MTLPs were similar between the sites. Results suggested that differences in exposure history had no influence on the bioaccumulation of $\mathrm{Cd}$, but did affect the concentrations of $\mathrm{Cd}$ bound to MTLP during Cd exposure in these insects.
\end{abstract}

Keywords-Bioaccumulation Detoxification Cadmium Exposure history Aquatic insect

\section{INTRODUCTION}

Humankind's use of metals has resulted in the extensive contamination of freshwater ecosystems [1] that has had harmful effects on fauna, including the aquatic insects [2], a highly diverse and ecologically important group. Structural and functional features of insect species assemblages can indicate ecological impacts by metals [2,3], and some species have been developed to monitor metal exposure [4]. The mechanistic basis for ecological changes caused by metals is not well known, however. This partly is because physiological mechanisms determining metal bioaccumulation and toxicity are not known for most species [4-6]. The genus Hydropsyche, a filter-feeding caddisfly, commonly is found in low to moderately contaminated streams. Here, we address the physiological basis for the insect's observed metal tolerance in a comparative study of populations having different exposure histories.

Comparative studies of populations can provide insights to protective mechanisms and the toxicological implications of metal body burdens of resident populations. Organisms that inhabit contaminated sites must possess the physiological means to prevent the toxic accumulation of metals at target sites. To avoid toxicity, uptake and elimination kinetics need to constrain the accumulation rates of metals to levels commensurate with the organism's capacity for detoxification and storage [7]. A species may either possess these traits already or develop them through physiological acclimation or the selection of resistant genotypes. Thus, populations inhabiting contaminated sites might express bioaccumulation kinetics

* To whom correspondence may be addressed (djcain@usgs.gov).

Any use of firm, trade, and brand names is for identification purposes only and does not constitute endorsement by the U.S. Government. and/or subcellular metal partitioning patterns distinct from uncontaminated populations $[8,9]$ if metal exposure modified fluxes of metals either into or out of the body and/or enhanced detoxification mechanisms.

Considerable attention has been directed at the subcellular mechanisms involved in metal detoxification [7,10]. These mechanisms include detoxification by metallothioneins, a family of inducible metal-binding proteins, and sequestration and storage in structures such as granules. The signaling pathway for metallothionein induction is highly sensitive to the uptake of $\mathrm{Cd}$. Pre-exposure to even low levels of $\mathrm{Cd}$ has been shown to increase translation rates of metallothionein relative to organisms that were not pre-exposed [11,12]. The increase in metal-binding capacity by induced metallothionein is related to increased protection against toxicity [11]. The proliferation of intracellular granules in metal-contaminated organisms suggests that this is another means to reduce metal interactions with target sites [13].

The effect of metal pre-exposure on metal uptake and elimination is not as well studied as subcellular mechanisms. Evidence from experimental and field studies of invertebrates shows that pre-exposure can affect rates of metal accumulation [8,14-16], although a response may depend on a number of factors, including pre-exposure concentrations and the resulting body burdens [16,17], and species- and metal-specific mechanisms controlling accumulation and detoxification $[18,19]$. For example, studies of Cd in marine bivalves suggests that, when pre-exposures raised body burdens to relatively high concentrations, dietary uptake of the element increased, possibly in response to increased binding of $\mathrm{Cd}$ to metallothioneinlike proteins (MTLP) $[14,16]$. However, this response does not always occur in nature [17], perhaps because exposure levels and the associated tissue concentrations are not high enough 


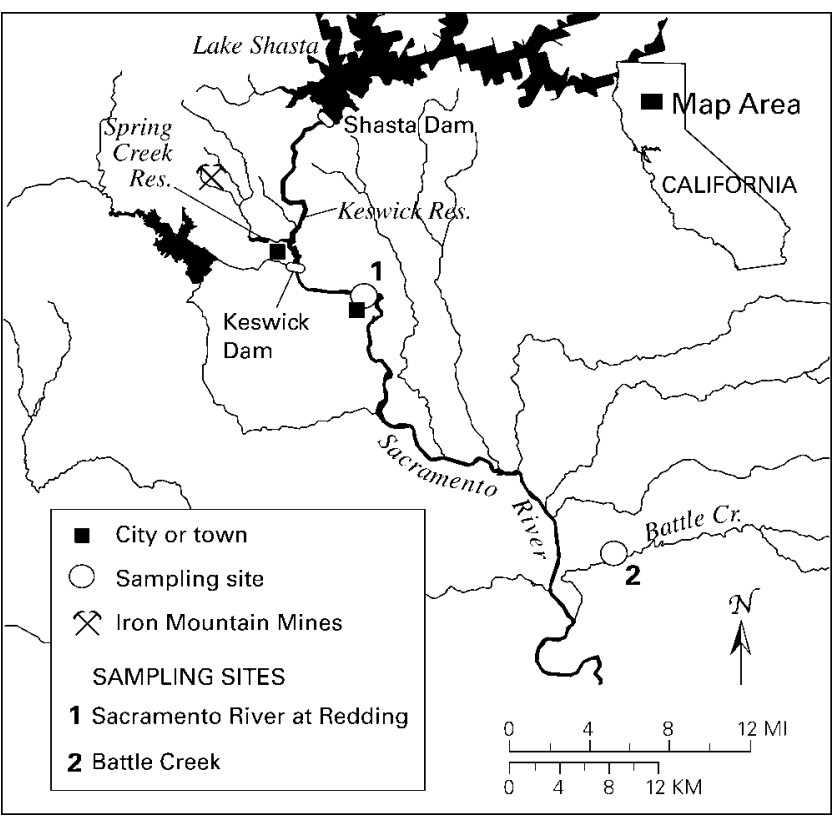

Fig. 1. Map of upper Sacramento River (CA, USA) showing the sites where Hydropsyche californica were collected for this study. The Sacramento River at Redding is contaminated chronically from mine waste draining into the Sacramento River via Spring Creek and Keswick Reservoirs. Battle Creek is an uncontaminated tributary of the Sacramento River.

to affect metal kinetics. In contrast to bivalves, a barnacle was not affected by pre-exposure, a difference that may be related to the fact that this organism stored excess metals in intracellular granules, relying less on MTLP for detoxification $[18,20]$. Effects of pre-exposure on uptake from solution rarely have been observed in invertebrates [15]. Rainbow et al. [20] suggested that effects on solute uptake may be expressed only where strong selective pressure is exerted from high chronic exposures. Therefore, the existing literature suggests that rates of metal uptake and loss may be modified in some species if metal exposures are high enough either to induce physiological acclimation or exert strong selective pressures for resistant genotypes. Where populations are exposed to low to moderate levels of contamination, a common occurrence, effects on metal kinetics are less certain.

Here, we examine the effects of a history of moderate metal exposure [21,22] on rates of accumulation and elimination and intracellular partitioning of $\mathrm{Cd}$ in the caddisfly Hydropsyche californica following aqueous exposure. Aspects of metal bioaccumulation and tolerance in the genus have been considered previously $[6,23]$; however, no study has attempted to determine whether metal-exposure history modifies physiological processes related to $\mathrm{Cd}$ bioaccumulation and detoxification, which thereby could affect the vulnerability of Hydropsyche to metals.

\section{MATERIALS AND METHODS}

\section{Source populations}

Insects used for the study were collected on October 13, 2003, from two sites, the Sacramento River at Redding and Battle Creek, located in the catchment of the upper Sacramento River (CA, USA; Fig. 1). The upper Sacramento River has a long history of metal contamination due to drainage from basemetal mines in the watershed [21]. Metals, including $\mathrm{Cu}, \mathrm{Cd}$, and $\mathrm{Zn}$, drain from inoperative mines on Iron Mountain into
Spring Creek and contaminate water [21], sediments, and invertebrates [22] in the upper Sacramento River downstream of Keswick Reservoir (Fig. 1). A previous study showed that $\mathrm{Cd}$, in particular, was bioaccumulated by resident caddisflies in the upper Sacramento River [22]. Therefore, caddisflies collected from the Sacramento River at Redding for this study were assumed to have been exposed chronically to Cd. Animals also were collected from Battle Creek approximately 8 $\mathrm{km}$ upstream of its mouth. Battle Creek is a tributary of the Sacramento River located more than $30 \mathrm{~km}$ downstream of Redding. It has no documented anthropogenic enrichment of metals and, therefore, we expected it to represent a reference condition.

Caddisflies from each site were collected by hand from cobble and boulders gathered in $<0.3-\mathrm{m}$ water depth. Individuals were removed carefully from their retreats to avoid injury and placed into Whirl Pak ${ }^{\circledR}$ bags (NASCO, Modesto, CA, USA) filled with site water. Bags were placed in an ice cooler for transport to the laboratory the same day of collection.

\section{Laboratory procedures and elemental analysis}

Insects were transported to an environmentally controlled room with a light:dark photoperiod of $16: 8 \mathrm{~h}$ and a constant temperature of $15^{\circ} \mathrm{C}$. Several individuals from each site were collected randomly for taxonomic identification. The remaining animals were transferred to soft artificial river water (48 $\mathrm{mg} / \mathrm{L} \mathrm{NaHCO}_{3}, 30 \mathrm{mg} / \mathrm{L} \mathrm{CaSO}_{4} \cdot 2 \mathrm{H}_{2} \mathrm{O}, 30 \mathrm{mg} / \mathrm{L} \mathrm{MgSO}_{4}$, and $2 \mathrm{mg} / \mathrm{L} \mathrm{KCl}$, nominal hardness of 40-48, nominal alkalinity of 30-35, and $\mathrm{pH}$ 6.8) [24]. This water was used throughout the experiment in order to facilitate comparisons of results with other species examined in our laboratory [5]. Insects were acclimated to laboratory conditions for $4 \mathrm{~d}$ before experimentation and fed a diet consisting of alfalfa and Spirulina aquarium flake food (Ocean Star International Marine Lab, Burlingame, CA, USA) ad libitum. On the second day of acclimation, depuration of unassimilated, metal-contaminated food present in the animals' guts at the time of collection was assumed largely to be complete [25]. Thus, individuals from the Sacramento River $(n=5)$ and Battle Creek $(n=10)$ were placed into individual acid-washed polypropylene snap-cap vials with a small amount of artificial stream water (to prevent desiccation) and then frozen for subsequent elemental analysis. The remaining animals were acclimated for two more days. These insects were not fed for $1 \mathrm{~d}$ before experiments to reduce production of feces that could bind solute metal and alter exposure conditions. Only apparently healthy, active animals were used in the experiments.

Metal exposures at the two sites were assessed by analyzing whole body metal concentrations of those animals sampled on the second day of acclimation (see above, this section). Hydropsyche were prepared using trace element clean techniques following a micro-digestion procedure described by Croteau et al. [26]. Samples were analyzed by inductively coupled plasma-mass spectrometry.

\section{Experimental design}

The experimental exposures were conducted in the environmentally controlled room at the same temperature and photoperiod as described above (see Laboratory procedures and elemental analysis section). Exposure chambers were four 1$\mathrm{L}$ polypropylene beakers. A piece of $0.5-\mathrm{mm}$ nylon mesh (11 $\times 16.5 \mathrm{~cm}$ ) was placed in each beaker to provide an attachment 
surface for the insects. Air was bubbled steadily into the containers to maintain dissolved oxygen concentrations and provided constant water movement. Nominal experimental exposures were set at $518 \mathrm{ng} \mathrm{Cd} / \mathrm{L}(\sim 4 \mathrm{nM})$, an environmentally realistic level of contamination [26]. This concentration was expected to induce detoxification mechanisms and avoid acute toxicity. Artificial soft river water $(1.0 \mathrm{~L})$ was spiked with 0.5 $\mathrm{ml} \mathrm{CdCl}{ }_{2}$ stock solution $\left(1 \mu \mathrm{g} \mathrm{Cd} / \mathrm{ml}\right.$ in $0.1 \mathrm{~N}^{-\mathrm{HNO}_{3}}$ ), $2.0 \mathrm{ml}$ ${ }^{109} \mathrm{CdCl}_{2}$ stock solution $\left(9 \mathrm{ng} \mathrm{Cd} / \mathrm{ml}\right.$ in $0.1 \mathrm{~N} \mathrm{HNO}_{3}$ having a specific activity of $2.14 \mu \mathrm{Ci} / \mathrm{L}$ ). The $\mathrm{pH}$ was adjusted to 6.8 by the addition of $0.1 \mathrm{~N} \mathrm{NaOH}$. Forty individuals from each site were divided randomly between replicate exposure chambers $(2$ exposure chambers per site $\times 20$ individuals per chamber) and then exposed for $6 \mathrm{~d}$ without feeding. The exposure was terminated after $6 \mathrm{~d}$ to avoid starvation. After each day of exposure, 10 individuals were subsampled randomly from each exposure chamber ( $n=20$ for each site), rinsed with unspiked artificial river water, transferred to 20 -ml vials containing artificial river water, assayed in vivo for radioactivity, weighed, and then returned to their respective exposure chambers. Water in the exposure chambers was assayed each day and renewed on days two and four.

After $6 \mathrm{~d}$ of exposure, half of the individuals from each site were rinsed with artificial river water, placed into vials, and then stored at $-80^{\circ} \mathrm{C}$ for subsequent subcellular fractionation. The remaining individuals were rinsed and transferred to separate $2-\mathrm{L}$ aquaria equipped with a circulating pump and activated carbon filters. A small amount of gravel and small cobbles collected from Battle Creek, the reference site, was placed in the aquaria. Insects were provided additional food (Spirulina aquarium flake food, Ocean Star International Marine $\mathrm{Lab}$ ) and maintained in these systems for $9 \mathrm{~d}$. Water was assayed daily for radioactivity, and the carbon filters and water were changed as needed.

At least half of the individuals from each site were subsampled randomly and assayed for radioactivity during the depuration phase ( $n=15-17$ for Battle Creek and $n=10-$ 14 for the Sacramento River). Animals were assayed daily for the first $5 \mathrm{~d}$ and thereafter every $2 \mathrm{~d}$. Individuals were rinsed with artificial stream water, placed into counting vials filled with artificial water for in vivo assay, and afterward returned to their aquaria. Depuration was terminated after $9 \mathrm{~d}$, at which time most of the radioactivity had been eliminated from the insects. Insects were counted a final time, then sealed in counting vials (without water) and stored at $-80^{\circ} \mathrm{C}$.

Subcellular fractions were obtained on samples collected at the end of the exposure (day 6) and depuration (day 15) in order to determine if the distribution of $\mathrm{Cd}$ changed during depuration. Subcellular fractions were prepared by differential centrifugation, combined with chemical or heat treatment of some of the fractions as described previously [6,27]. Whole larvae were thawed partially and weighed. Eight to 10 larvae were combined to prepare a composite sample with ample biomass $(\sim 200 \mathrm{mg})$ for tissue homogenization and then assayed to obtain the initial radioactivity. The samples were homogenized with a Polytron ${ }^{\circledR}$ (Brinkmann Instruments, New York, NY, USA) in $0.05 \mathrm{M}$ Tris- $\mathrm{HCl}$ buffer (refrigerated, $\mathrm{N}_{2}$ saturated, $\mathrm{pH}$ 7.4) for $1 \mathrm{~min}$. The homogenate was separated sequentially into six operationally defined subcellular fractions comprising the cell debris containing metals solubilized from the $800 \mathrm{~g}$ pellet by digestion in $0.5 \mathrm{~N} \mathrm{NaOH}$ for $1 \mathrm{~h}$ at $70^{\circ} \mathrm{C}$, a residual, nonbiologically active fraction containing metals not solubilized by the $\mathrm{NaOH}$ treatment, intracellular organelles (i.e., mitochondria, lysosomes, microbodies), microsomal fraction, cytosolic proteins denatured by heat treatment, and heatstable cytosolic proteins. Heat-stable cytosolic proteins were not characterized further but were assumed to represent metallothionein-like proteins [28]. Hereafter, the heat-stable and heat-denatured protein fractions are referred to as metallothionein-like proteins (MTLP) and nonmetallothionein-like proteins (non-MTLP), respectively. Subcellular fractions immediately were counted for radioactivity.

Cadmium concentrations of the subcellular fractions were summed into operationally defined metal-sensitive and detoxified compartments for the insects from each site [27] for comparative purposes. The metal-sensitive compartment included the non-MTLP, microsomes, and organelles, and the detoxified metal compartment included the MTLP. Metals solubilized by $\mathrm{NaOH}$ digestion were combined with the residual fraction into a single compartment that we termed cell debris. We did not attribute any toxicological significance to this compartment because it likely contains metals bound to both sensitive (e.g., nonspecific binding to membrane-bound proteins and nuclear components) and nonsensitive sites (e.g., nonspecific binding to chitin). The $\mathrm{NaOH}$ digestion is intended to isolate a residual fraction containing metal-rich granules [27]. However, it is unlikely that these structures were formed during the short exposure time and low $\mathrm{Cd}$ concentration of our experiment [7]. Therefore, the functional role of the residual fraction probably does not represent a detoxification product as conceived by Wallace et al. [27].

\section{Data analysis}

Radioactivity (disintegrations per min) of the samples was calibrated against prepared standards and converted to tissue concentrations of $\mathrm{Cd}$ (ng/g wet wt). Growth was not noticeable from the mean wet weights of samples recorded during the course of the experiment and, therefore, was not considered in the calculation of tissue concentration. The proportional distribution of $\mathrm{Cd}$ among subcellular fractions was based on the summation of all fractions and not the initial whole body concentrations, because recovery of Cd was less than $100 \%$ (see Subcellular distribution section).

Rates of Cd accumulation (ng/g/d) and proportional loss (per d) in insects from the two sites were compared using analysis of covariance, in which $\mathrm{Cd}$ accumulation was the dependent variable, day was the continuous variable, and site was the categorical factor. Curves for $\mathrm{Cd}$ accumulation during the exposure phase of the experiment were fit by linear regression and the slopes were analyzed for significant difference $(p<0.05)$. The loss curves were examined from the logtransformed proportional concentrations $\left(\mathrm{Cd}_{t} / \mathrm{Cd}_{0}\right.$ where $\mathrm{Cd}_{t}$ is the $\mathrm{Cd}$ concentration on a given day during depuration and $\mathrm{Cd}_{0}$ is the initial $\mathrm{Cd}$ concentration). Portions of the curve that displayed relatively slow and constant loss over time were analyzed by analysis of covariance to compare loss rates between sites. The efflux rate constants, $k_{e}$ (per d), were estimated from the slopes of these lines. Comparisons of $\mathrm{Cd}$ in whole bodies and subcellular fractions of insects between the sites were made with analysis of variance. Data were transformed as necessary to meet the assumptions of the model. If transformation did not correct the data, then the Kruskal-Wallis analysis of variance was performed. Statistica software (Version 7) by StatSoft (Tulsa, OK, USA) was used for all statistical analysis. 
Table 1. Metal concentrations of Hydropsyche californica (whole body, dry wt, mean \pm 1 standard deviation, $n=5-10$ ) from Battle Creek (CA, USA) and the Sacramento River at Redding (CA, USA) in October 2003. An asterisk indicates a significant difference in the metal concentration of insects between the sites $(p<0.05)$

\begin{tabular}{lccc}
\hline & \multicolumn{3}{c}{ Concn. $(\mu \mathrm{g} / \mathrm{g})$} \\
\cline { 2 - 4 } Site & $\mathrm{Cd}$ & $\mathrm{Cu}$ & $\mathrm{Zn}$ \\
\hline Battle Creek & $0.05 \pm 0.03^{*}$ & $18.8 \pm 5.0$ & $111 \pm 31$ \\
Sacramento River & $1.05 \pm 0.26^{*}$ & $23.2 \pm 2.8$ & $120 \pm 12$ \\
\hline
\end{tabular}

\section{Instrumentation and quality control}

All gamma counting was performed using a Wallac 1480 gamma counter (Gaithersburg, MD, USA) equipped with a NaI crystal. Counting times were for $3 \mathrm{~min}$, producing counting errors of $<10 \%$. Radioactivity was calibrated with prepared counting standards and blanks and was corrected for decay and counting efficiency. Percent recovery of radioactivity in whole organisms from the subcellular fractions were comparable between sites, ranging from 76 to $81 \%$ with means \pm 1 standard deviation of $79 \pm 4$ and $76 \pm 2$ for insects from Battle Creek and the Sacramento River, respectively.

Nonradioactive metals analysis was performed with a Perkin-Elmer (Wellesley, MA, USA) Elan 6000 (single detector, quadrapole) inductively coupled plasma-mass spectrometry. Quality control for elemental analysis by inductively coupled plasma-mass spectrometry included re-analysis of a calibration standard ( every 10 analyses) and analysis of process blanks and certified reference material for biological tissue (Tort-2, National Research Council Canada, Ottawa, ON, Canada). Method detection limits for $\mathrm{Cd}, \mathrm{Cu}$, and $\mathrm{Zn}$ were $<0.001$, 0.001 , and $0.010 \mu \mathrm{g} / \mathrm{L}$, respectively. Results for process blanks and the reference material (mean $\pm 95 \%$ confidence interval) are summarized. Process blanks for $\mathrm{Cu}$ and $\mathrm{Zn}$ were $0.08 \pm$ 0.09 and $0.88 \pm 1.44 \mu \mathrm{g} / \mathrm{L}$, respectively. Cadmium was not detected. Measured concentrations in Tort- 2 were $24.9 \pm 1.5$ $\mu \mathrm{g} \mathrm{Cd} / \mathrm{g}, 105 \pm 0.4 \mu \mathrm{g} \mathrm{Cu} / \mathrm{g}$, and $142 \pm 17 \mu \mathrm{g} \mathrm{Zn/g}$. Measured concentrations of $\mathrm{Cd}$ and $\mathrm{Cu}$ agreed with the certified means $(26.7 \pm 0.6 \mu \mathrm{g} \mathrm{Cd} / \mathrm{g}$ and $106 \pm 10 \mu \mathrm{g} \mathrm{Cu} / \mathrm{g})$, and the measured $\mathrm{Zn}$ concentrations were $21 \%$ less than the certified mean (180 $\pm 6 \mu \mathrm{g} \mathrm{Zn/g)}$.

\section{RESULTS}

\section{Site-specific body burdens}

Concentrations of $\mathrm{Cd}, \mathrm{Cu}$, and $\mathrm{Zn}$ measured in resident caddisflies $2 \mathrm{~d}$ after they were collected are shown in Table 1. Caddisflies from the Sacramento River were enriched in $\mathrm{Cd}$ relative to Battle Creek $(p<0.05)$, and $\mathrm{Cu}$ and $\mathrm{Zn}$ concentrations were not significantly different between the two sites.

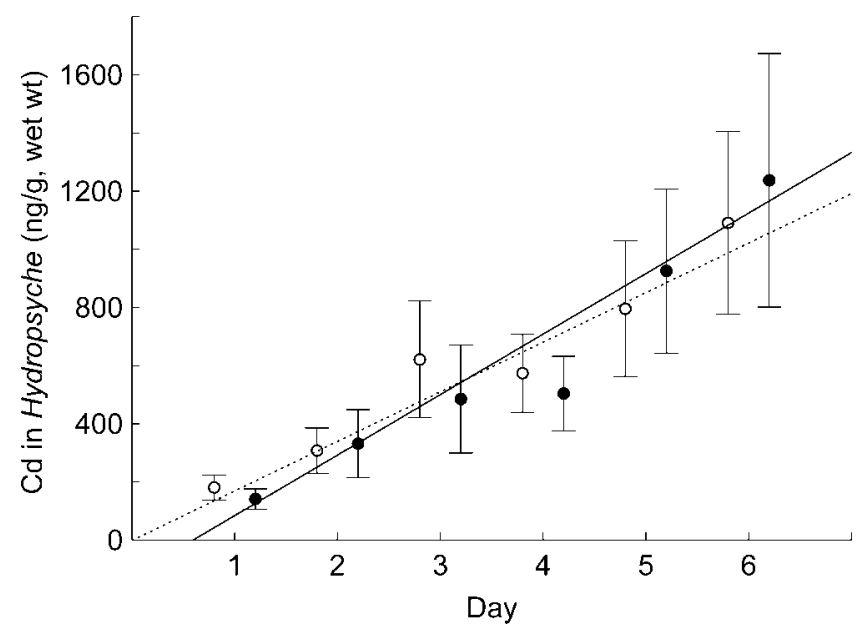

Fig. 2. Cadmium accumulation in Hydropsyche californica collected from Battle Creek (CA, USA; reference site; open symbol, dashed line) and the Sacramento River (CA, USA; contaminated site; closed symbol, solid line), and subsequently exposed for $6 \mathrm{~d}$ to dissolved $\mathrm{Cd}(0.518 \mu \mathrm{g} / \mathrm{L}$, nominal $)$. Data are the mean \pm 1 standard deviation for $n=10$ and were fit by linear regression.

\section{Cadmium accumulation and loss}

Cadmium increased steadily and similarly in insects from both sites and did not reach steady state during the 6-d exposure (Fig. 2). The $\mathrm{Cd}$ accumulation rates estimated by the slopes of the linear regressions of the observed Cd tissue concentrations over days one through six were $157 \pm 43$ (mean $\pm 95 \%$ confidence interval) and $186 \pm 48 \mathrm{ng} / \mathrm{g} / \mathrm{d}$ for Battle Creek and the Sacramento River, respectively (Table 2). These rates were not significantly different $(p<0.05)$. The mean for the combined data was $171 \pm 31 \mathrm{ng} / \mathrm{g} / \mathrm{d}$.

Elimination of $\mathrm{Cd}$ during the 9-d depuration phase of the experiment was biphasic, characterized by rapid loss $(\sim$ half the body burden) within the first day, followed by a slower phase of loss for the remaining $8 \mathrm{~d}$ (Fig. 3). Only about $10 \%$ of the accumulated $\mathrm{Cd}$ was retained at the end of the experiment. Data from days one through nine were used to compare elimination from the slower compartment, which probably better represented the physiological loss of $\mathrm{Cd}$ from the animals. Analysis of covariance did not detect any difference in the slopes of the curves between the sites. The estimated efflux rate constants were $0.20 \pm 0.02 / \mathrm{d}$ for Battle Creek and 0.24 $\pm 0.04 / \mathrm{d}$ for the Sacramento River (Table 2). Biological halflives of Cd were 3.4 and $2.9 \mathrm{~d}$ for Battle Creek and the Sacramento River, respectively (Table 2).

\section{Subcellular distribution}

Although $\mathrm{Cd}$ body burdens were similar between insects from the two sites at the end of the exposure phase of the

Table 2. The mean body weight, $\mathrm{Cd}$ accumulation rate, Cd efflux rate constant $\left(k_{\mathrm{e}}\right)$, and biological halflife of Cd in Hydropsyche californica from two sites. Battle Creek (CA, USA) was the reference site and Sacramento River (CA, USA) was the contaminated site. The mean body weights were derived from repeated measurements of randomly selected individuals assayed for radioactivity during the experiment. The estimated rates are based on wet weight. The errors associated with the means are the 95\% confidence intervals

\begin{tabular}{lcccc}
\hline Site & $\begin{array}{c}\text { Wet wt } \\
(\mathrm{mg})\end{array}$ & $\begin{array}{c}\text { Accumulation rate } \\
(\mathrm{ng} / \mathrm{g} / \mathrm{d})\end{array}$ & $\begin{array}{c}k_{\mathrm{e}} \\
(/ \mathrm{d})\end{array}$ & $\begin{array}{c}t_{1 / 2} \\
(/ \mathrm{d})\end{array}$ \\
\hline Battle Creek & $26.6 \pm 1.1$ & $157 \pm 43$ & $0.20 \pm 0.02$ & 3.4 \\
Sacramento River & $24.6 \pm 1.8$ & $186 \pm 48$ & $0.24 \pm 0.04$ & 2.9 \\
\hline
\end{tabular}




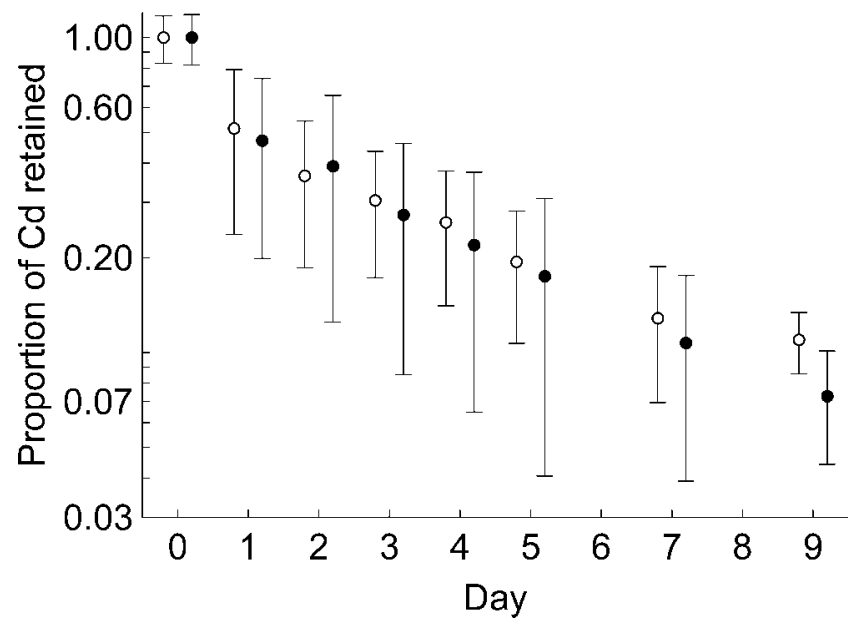

Fig. 3. Retention of Cd in Hydropsyche californica from Battle Creek (CA, USA; reference site; open symbol) and the Sacramento River (CA, USA; contaminated site; closed symbol) following a 6-d exposure to dissolved $\mathrm{Cd}$. Data are the mean \pm 1 standard deviation for $n=2$ to 17 .

experiment, the subcellular distribution of Cd differed, particularly with respect to the cytosolic MTLPs and non-MTLPs. The whole-body concentrations in samples used for subcellular fractionation were $1,132 \pm 87 \mathrm{ng} / \mathrm{g}$ (mean \pm 1 standard deviation) and 1,269 $\pm 335 \mathrm{ng} / \mathrm{g}$ for Battle Creek and the Sacramento River, respectively. Total concentrations of cytosolic Cd (MTLP + non-MTLP) in the insects were comparable between sites and accounted for approximately $40 \%$ of the total recovered $\mathrm{Cd}$ (Fig. 4). However, the relative distributions of Cd between MTLP and non-MTLP were different between the sites. In the insects from Battle Creek, somewhat more $\mathrm{Cd}$ was associated with the MTLP fraction $(25 \pm 1 \%$ of the total recovered $\mathrm{Cd}$ or $60 \pm 0 \%$ of the cytosol) than the non-MTLP fraction $(18 \pm 1 \%$ of the total recovered $\mathrm{Cd}$ or $40 \%$ of the cytosol). In the Sacramento River group, $\mathrm{Cd}$ primarily was associated with MTLP, accounting for $36 \pm 4 \%$ of the recovered $\mathrm{Cd}$ or $89 \pm 2 \%$ of the total cytosolic Cd burden. Only 5 $\pm 1 \%$ of the total recovered Cd was in the non-MTLP fraction of insects from the Sacramento River, which was significantly less $(p<0.05)$ than insects from Battle Creek. Average concentrations of Cd bound to MTLP in the Battle Creek and Sacramento River insects were, respectively, $201 \pm 10 \mathrm{ng} / \mathrm{g}$ and $346 \pm 105 \mathrm{ng} / \mathrm{g}$ and $(p>0.05$; Table 3). Concentrations of $\mathrm{Cd}$ bound to non-MTLPs were significantly greater in the insects from Battle Creek $(134 \pm 7 \mathrm{ng} / \mathrm{g})$ than in those from the Sacramento River $(42 \pm 2 \mathrm{ng} / \mathrm{g})(p<0.05)$. Thus, the concentrations of $\mathrm{Cd}$ bound to potentially metal-sensitive cy-

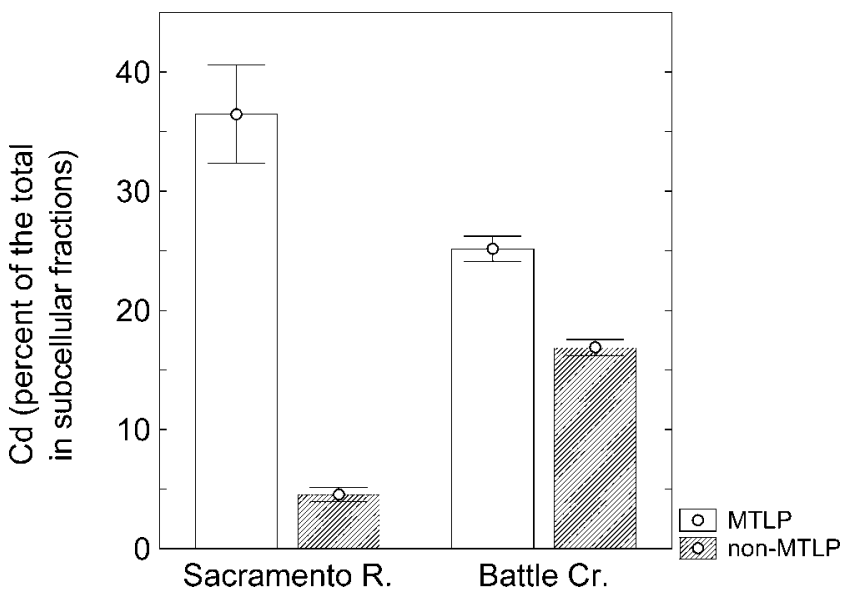

Fig. 4. Cadmium accumulation (percent of total recovered in subcellular fractions) in cytosolic metallothionein-like proteins (MTLP) and non-MTLP in Hydropsyche californica from Battle Creek (CA, USA; reference site) and the Sacramento River (CA, USA; contaminated site) after a 6-d exposure to dissolved Cd $(0.518 \mu \mathrm{g} / \mathrm{L}$, nominal $)$. Data are the mean \pm 1 standard deviation $(n=2$ composites, each with $8-10$ individuals).

tosolic proteins differed by more than threefold between the sites. Cadmium concentrations in the other subcellular fractions were not significantly different between the sites (Table 3 ). The quantity of $\mathrm{Cd}$ associated with the cell debris was relatively high $(37-46 \%)$ comparable to the cytosol. The organelles and microsomal fractions each contained relatively small amounts $(<12 \%)$ of the accumulated $\mathrm{Cd}$.

The partitioning patterns of the detoxified and metal-sensitive compartments of the subcellular fractions differed between sites (Fig. 5). In the insects from Battle Creek, more $\mathrm{Cd}$ was accumulated in the metal-sensitive compartment than in the detoxified compartment, the two compartments representing $38 \pm 6 \%$ and $25 \pm 1 \%$, respectively, of the recovered $\mathrm{Cd}$. The metal-sensitive and detoxified compartments in the Sacramento River insects contained $17 \pm 1 \%$ and $36 \pm 4 \%$ of the recovered $\mathrm{Cd}$, respectively. The percent of $\mathrm{Cd}$ in each compartment was significantly different between the sites $(p<0.05)$. The compartmentalization of $\mathrm{Cd}$ in insects from each site largely reflected the Cd concentrations in MTLPs and non-MTLPs.

Cadmium was eliminated from all subcellular fractions (Table 3). Furthermore, no subcellular fraction in the tissues of insects from either site appeared to retain a disproportionate amount of the $\mathrm{Cd}$ body burden. For example, 83 to $95 \%$ of accumulated $\mathrm{Cd}$ was eliminated from both cytosolic protein pools. As a result, the absolute and relative concentrations of

Table 3. Cadmium (ng/g wet wt, mean \pm 1 standard deviation) in subcellular fractions of the tissues of Hydropsyche californica from two sites (CA, USA). Battle Creek was the reference site and Sacramento River was the contaminated site. Subcellular fractionation was performed after $6 \mathrm{~d}$ of exposure to aqueous Cd (exposure phase, $n=2$ composites) and after $9 \mathrm{~d}$ of depuration (depuration phase, $n=1$ composite). The MTLP and non-MTLP fractions are, respectively, the metallothionein-like protein and non-metallothionein-like protein fractions of the cytosol. An asterisk indicates a significant difference in the concentration of Cd within a subcellular fraction between the sites $(p<0.05)$

\begin{tabular}{|c|c|c|c|c|c|c|}
\hline \multirow{2}{*}{$\begin{array}{l}\text { Phase of } \\
\text { experiment }\end{array}$} & \multirow[b]{2}{*}{ Site } & \multicolumn{5}{|c|}{ Subcellular fractions } \\
\hline & & MTLP & Non-MTLP & Organelles & Microsomes & Cell debris \\
\hline \multirow[t]{2}{*}{ Exposure } & Battle Creek & $201 \pm 10$ & $134 \pm 7 *$ & $85 \pm 29$ & $78 \pm 4$ & $302 \pm 82$ \\
\hline & Sacramento River & $346 \pm 105$ & $42 \pm 2 *$ & $51 \pm 17$ & $69 \pm 18$ & $430 \pm 39$ \\
\hline \multirow[t]{2}{*}{ Depuration } & Battle Creek & 23 & 14 & 4 & 5 & 44 \\
\hline & Sacramento River & 18 & 7 & 5 & 5 & 22 \\
\hline
\end{tabular}


A

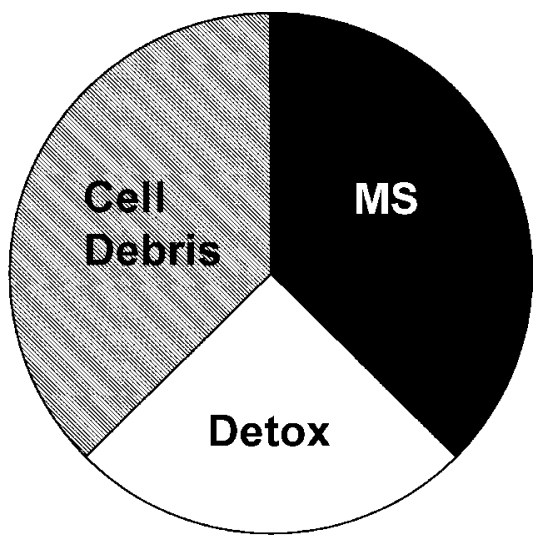

B

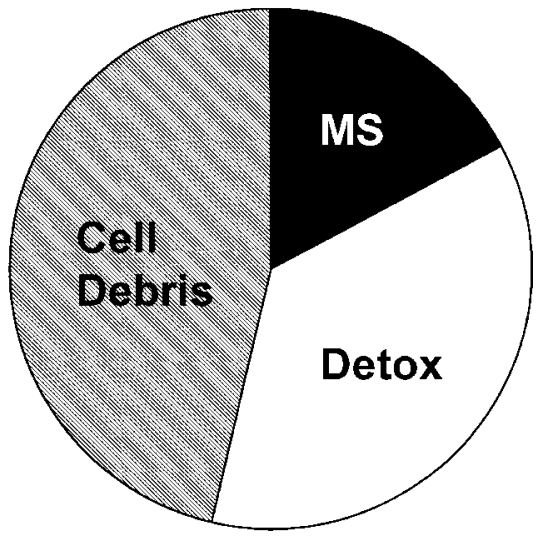

Fig. 5. The pie charts represent the proportional distribution of $\mathrm{Cd}$ among detoxified (Detox) and metal-sensitive (MS) subcellular compartments and the cell debris in Hydropsyche californica after a 6-d exposure to dissolved $\mathrm{Cd}(0.518 \mu \mathrm{g} / \mathrm{L}$, nominal). Battle Creek (CA, USA; reference site) is shown in the top panel (A), and the Sacramento River (CA, USA; contaminated site) is shown in the bottom panel (B).

Cd in the MTLP and non-MTLPs were similar between the sites at the end of depuration (Table 3 ).

\section{DISCUSSION}

Cadmium concentrations in Hydropsyche from Battle Creek were equivalent to those found in a regional reference stream sampled in an earlier study [22], verifying the lack of a contamination history in Battle Creek. The upper Sacramento River has a long history of contamination by a mixture of metals due to drainage from base-metal mines in the watershed [21]. Metal concentrations in water [21], river channel sediments [22], and $H$. californica [22] decrease downstream from documented metal sources. From samples collected in 1997, Cain et al. [22] noted that concentrations of $\mathrm{Cd}$ in the cytosol of $H$. californica (used to indicate exposure to bioavailable metal) was elevated particularly relative to other metals, including $\mathrm{Cu}$ and $\mathrm{Zn}$. Cadmium also was elevated in samples collected for this study in October 2003, exceeding concentrations in Battle Creek by more than an order of magnitude. Because the life cycle of hydropsychid caddisflies is typically one year, it is likely that $H$. californica residing in the upper Sacramento River were exposed to moderate levels of $\mathrm{Cd}$ and other metals over many generations. To our knowledge, no studies have been conducted to determine if the population has evolved resistance to metals.

No evidence supported that exposure history modified either uptake or efflux of aqueous $\mathrm{Cd}$ in $\mathrm{H}$. californica. Rates of $\mathrm{Cd}$ accumulation and efflux essentially were the same for the insects from both sites. These results are consistent with most studies that have examined aquatic invertebrates collected from sites having different levels of metal contamination $[17,20,29]$. Effects, when they were observed, appeared to involve small changes in dietary uptake of metals in animals having relatively high body burdens [16]. Effects of exposure history on dietary processes affecting $\mathrm{Cd}$ bioaccumulation in Hydropsyche should be considered in future studies. However, it appears that modification of metal fluxes in wild populations is uncommon and may be noticeable only where extreme exposures have selected for resistant genotypes.

Information on uptake kinetics in Hydropsyche that we can compare to our results is limited to two other studies. Buchwalter and Luoma [5] reported $\mathrm{Cd}$ accumulation rates in $H$. californica and Hydropsyche oslari of 0.45 and $0.29 \mathrm{ng} / \mathrm{g} / \mathrm{h}$, respectively, over $4 \mathrm{~h}$ of exposure at $32 \mathrm{ng} / \mathrm{L}$. Converting these data to $\mathrm{ng} / \mathrm{g} / \mathrm{d}$ and dividing by the exposure concentration gives estimates of 0.34 and $0.22(\mathrm{~L} / \mathrm{g} / \mathrm{d})$ for the uptake rate constant, $k_{u}$. The estimated uptake rate constant for our experimental conditions was 0.34 , similar to those reported by Buchwalter and Luoma [5]. Evans et al. [30] extracted $k_{u}$ for $\mathrm{Cd}$ in $\mathrm{Hy}$ dropsyche betteni by modeling the observed accumulation data. The estimated uptake rate constant for that species was approximately 0.4 to $0.6 \mathrm{~L} / \mathrm{g} / \mathrm{d}$ (converted from the reported rate of $4 \mathrm{~L} / \mathrm{g}$ dry wt/d and assuming 85-90\% moisture content). From the limited data, uptake rates of $\mathrm{Cd}$ appear to be reasonably similar among species of Hydropsyche, and are moderately fast compared to some other insect species [5]. Nonetheless, physiological modification to reduce influx rates of $\mathrm{Cd}$ does not seem to be part of an adaptive response to chronic metal exposure.

Depuration of Cd was biphasic, suggesting the involvement of two compartments. Loss of $\mathrm{Cd}$ in the phantom midge, Chaoborus americanus, also appeared to involve two compartments [31]. The faster compartment possibly included $\mathrm{Cd}$ bound to low affinity sites, which quickly exchanged when the animals were moved into clean water. Our loss constant $\left(k_{e}\right)$ was based on elimination from the slower compartment, which others have argued usually dictates metal bioaccumulation over the longer exposure times experienced by animals in nature [32]. Our estimates of $k_{e}$ ranged from 0.20 to $0.24 / \mathrm{d}$, in close agreement with those reported for $H$. betteni $(0.21-0.24 / \mathrm{d})$ [30].

Increasing efflux rates in response to chronic metal exposure may not be a great selective advantage to Hydropsyche, because efflux of $\mathrm{Cd}$ already appears to be among the highest reported for an aquatic invertebrate. Rates in Hydropsyche roughly are comparable to those observed in the midge Chironomus riparius [33] and in a marine copepod [34], somewhat faster than in the phantom midge Chaoborus spp. [35], and more than an order of magnitude faster than rates observed in freshwater and marine bivalves [36,37] and a marine barnacle [20]. The fast elimination of $\mathrm{Cd}$ would be consistent with the relatively low $\mathrm{Cd}$ body burdens observed in the genus [6] and probably is an important trait allowing Hydropsyche to survive in metal-contaminated streams.

Cadmium primarily was accumulated in the cell cytosol and the cell debris. Lesser amounts were associated with the organelle (e.g., mitochondria and lysosomes) and the micro- 
somal fractions. These results generally agree with partitioning patterns observed in other aquatic species [6,27,38].

The partitioning of cytosolic Cd between MTLP and nonMTLP was the most distinguishing feature of $\mathrm{Cd}$ accumulation between insects from the reference site and the contaminated site. The induction of MTLPs by $\mathrm{Cd}$ is well-documented [7,11], and we assume that the 6-d exposure increased $\mathrm{Cd}$ tissue concentrations to levels sufficient to induce MTLPs in Hydropsyche. We cannot ascertain the mechanism responsible for the site-specific difference in Cd-MTLP concentrations at the end of the exposure period, although two explanations are plausible. The first assumes physiological acclimation, whereby pre-exposure to metals conditioned cells for increased synthesis of MT by promoting the transcription of mRNA [12]. Accordingly, metal exposures in the Sacramento River promoted transcription of (MTLP) mRNA in the individuals from that site. Higher concentrations of (MTLP) mRNA would increase rates of MTLP synthesis relative to the group from Battle Creek during the subsequent experimental exposure. Another mechanism that could increase (MTLP) mRNA transcription rates is gene duplication [39].

The association of $\mathrm{Cd}$ with non-MTLPs in insects from both sites indicated that induction of MTLP was not completely effective in blocking $\mathrm{Cd}$ from binding nonspecifically to other cytosolic ligands. However, in the Sacramento River insects, binding of Cd to MTLP appeared to be more effective at limiting interaction with non-MTLPs. Conversely, the partitioning pattern in the insects from Battle Creek suggests lower levels of MTLP were available to prevent the potentially more damaging effects associated with binding of $\mathrm{Cd}$ to other cytosolic ligands [38]. This raises the possibility that an unusual pulse of metal would have a greater adverse effect on a naïve population than on a population with a history of metal exposure.

Internal transport and storage of $\mathrm{Cd}$ could alter its tissue and subcellular distribution over time [40]. In this experiment, we obtained subcellular fractions at the end of the accumulation and depuration phases, but there was no evidence that the subcellular distribution of $\mathrm{Cd}$ in Hydropsyche changed under our experimental conditions. Losses of $\mathrm{Cd}$ occurred in all subcellular fractions at roughly the same rates. Thus, the proportional distributions of $\mathrm{Cd}$ among subcellular fractions at the end of the exposure phase and after $9 \mathrm{~d}$ of depuration were similar. Nearly all ( $\sim 90 \%)$ of the Cd accumulated in the MTLP fraction was eliminated from the animal over the 9-d depuration period, indicating a rapid turnover of MTLP-bound Cd. Also, there was no evidence that higher Cd-MTLP concentrations in the insects from the Sacramento River significantly affected the retention time of $\mathrm{Cd}$ in the body, because the $\mathrm{Cd}$ efflux rate was similar to the efflux rate in the insects from Battle Creek. Thus, increased levels of Cd-MTLP did not appear to alter the rate constant of loss.

A high proportion of Cd typically is associated with MTLP in Hydropsyche. Analyses of resident populations of Hydropsyche in the upper Sacramento River [22] and in the Clark Fork of the Columbia River (Montana, USA), in which sediments chronically are contaminated by metals [6], showed that the cytosol was a principal accumulation site for Cd, representing roughly 40 to $60 \%$ of the body burden. This is comparable to the results obtained from our experimental exposures. It also suggests that Hydropsyche does not store large amounts of the $\mathrm{Cd}$ body burden in intracellular granules [6]. High rates of $\mathrm{Cd}$ efflux are consistent with that observation.
Other processes also may prevent the build up of granules. It has been suggested that intracellular granules may be excreted at particular stages of an aquatic insect's lifetime, for example during molting [41].

Species of Hydropsyche are common members of benthic macroinvertebrate species assemblages in many river systems. They are considered relatively metal tolerant and often are a dominant taxon in streams affected by metals. The results of this study and others show that the genus possesses physiological qualities that could reduce its risk to metal exposure. Although uptake of dissolved Cd by Hydropsyche is relatively fast among aquatic insects [5], the rapid efflux of $\mathrm{Cd}$ by $\mathrm{Hy}$ dropsyche constrains its rate of accumulation. Metal exposure history had no detectable effect on either the uptake or efflux of aqueous $\mathrm{Cd}$ in the insects we tested, implying that site differences in metal contamination levels would not affect comparisons of metal bioaccumulation and, hence, interpretations of $\mathrm{Cd}$ bioavailability. Testing of more populations could determine whether this is a general phenomenon within the genus. However, the short biological half-life of $\mathrm{Cd}$ suggests that body burdens in resident populations reflect recent exposures. Biomonitoring designs need to consider this because fluctuations in exposures could be missed unless samples are collected frequently. A portion of the $\mathrm{Cd}$ body burden appears to be bound to MTLP, the putative detoxification mechanism. Exposure to moderate levels of Cd (e.g., as in the Sacramento River) can increase the Cd-MTLP binding capacity, thus enhancing the protection of metal-sensitive sites. Presumably, metal tolerances of resident populations could vary depending on their exposure histories. The ability to limit $\mathrm{Cd}$ bioaccumulation and increase detoxification of Cd by MTLP would appear to be highly effective traits in reducing the animal's risk to $\mathrm{Cd}$ exposure and likely are related to its observed metal tolerance and presence in metal-contaminated streams.

Acknowledgement-The study was supported by the National Research Program of the United States Geological Survey and by a National Research Council postdoctoral fellowship awarded to D.B. Buchwalter. The critical comments of M-N. Croteau and three anonymous reviewers greatly are appreciated.

\section{REFERENCES}

1. Nriagu JO, Pacyna JM. 1988. Quantitative assessment of worldwide contamination of air, water, and soils by trace metals. Nature 333:134-139.

2. Clements WH, Carlisle DM, Lazorchak JM, Johnson PC. 2000. Heavy metals structure benthic communities in Colorado mountain streams. Ecol Appl 10:626-638.

3. Carlisle DM, Clements WH. 2003. Growth and secondary production of aquatic insects along a gradient of $\mathrm{Zn}$ contamination in Rocky Mountain streams. J North Am Benthol Soc 22:582597.

4. Hare L. 1992. Aquatic insects and trace metals: Bioavailability, bioaccumulation, and toxicity. Crit Rev Toxicol 22:327-369.

5. Buchwalter DB, Luoma SN. 2005. Differences in dissolved cadmium and zinc uptake among stream insect: Mechanistic explanations. Environ Sci Technol 39:498-504.

6. Cain DJ, Luoma SN, Wallace WG. 2004. Linking metal bioaccumulation of aquatic insects to their distribution patterns in a mining-impacted river. Environ Toxicol Chem 23:1463-1473.

7. Mason AZ, Jenkins KD. 1995. Metal detoxification in aquatic organisms. In Tessier A, Turner DR, eds, Metal Speciation and Bioavailability in Aquatic Systems. John Wiley, New York, NY, USA, pp 479-606.

8. Boisson F, Hartl MGJ, Fowler SW, Amiard-Trinquet C. 1998. Influence of chronic exposure to silver and mercury in the field on the bioaccumulation potential of the bivalve Macoma balthica. Mar Environ Res 45:325-340.

9. Wallace WG, Lopez GR, Levinton JS. 1998. Cadmium resistance 
in an oligochaete and its effect on cadmium trophic transfer to an omnivorous shrimp. Mar Ecol Prog Ser 172:225-237.

10. Roesijadi G, Robinson WE. 1994. Metal regulation in aquatic animals: Mechanisms of uptake, accumulation, and release. In Malins DC, Ostrander GK, eds, Aquatic Toxicology. Molecular, Biochemical, and Cellular Responses. Lewis, Boca Raton, FL, USA, pp 387-420.

11. Klaassen CD, Liu J. 1998. Induction of metallothionein as an adaptive mechanism affecting the magnitude and progression of toxicological injury. Environ Health Perspect 106:297-300.

12. Unger ME, Roesijadi G. 1996. Increase in metallothionein mRNA accumulation during $\mathrm{Cd}$ challenge in oysters pre-exposed to $\mathrm{Cd}$. Aquat Toxicol 34:185-193.

13. Brown BE. 1982. The form and function of metal-containing 'granules' in invertebrate tissues. Biol Rev 57:621-667.

14. Blackmore G, Wang W-X. 2002. Uptake and efflux of Cd and Zn by the green mussel Perna viridis after metal pre-exposure. Environ Sci Technol 36:989-995.

15. Bryan GW, Hummerstone LG. 1971. Adaptation of the polychaete Nereis diversicolor to estuarine sediments containing high concentrations of heavy metals. I. General observations and adaptation to copper. J Mar Biol Assoc UK 51:845-863.

16. Shi D, Wang W-X. 2004. Understanding the differences in $\mathrm{Cd}$ and $\mathrm{Zn}$ bioaccumulation and subcellular storage among different populations of marine clams. Environ Sci Technol 38:449-456.

17. Blackmore G, Wang W-X. 2003. Comparison of metal accumulation in mussels at different local and global scales. Environ Toxicol Chem 22:388-395.

18. Rainbow PS, Ng TYT, Shi D, Wang W-X. 2004. Acute dietary pre-exposure and trace-metal bioavailability to the barnacle $\mathrm{Bal}$ anus amphitrite. J Exp Mar Biol Ecol 311:315-337.

19. Shi D, Blackmore G, Wang W-X. 2003. Effects of aqueous and dietary preexposure and resulting body burden on silver biokinetics in the green mussel Perna viridis. Environ Sci Technol 37:936-943.

20. Rainbow PS, Blackmore G, Wang W-X. 2003. Effects of previous field-exposure history on the uptake of trace metals from water and food by the barnacle Balanus amphitrite. Mar Ecol Prog Ser 259:201-213.

21. Alpers CN, Taylor HE, Domagalski JL. 1999. Metals transport in the Sacramento River, California, 1996-1997, Vol 1. Methods and data. Water Resources Investigations Report 99-4286. Department of the Interior, U.S. Geological Survey, Sacramento, CA.

22. Cain DJ, Carter JL, Fend SV, Luoma SN, Alpers CN, Taylor HE. 2000. Metal exposure to a benthic macroinvertebrate, Hydropsyche californica, related to mine drainage in the Sacramento River. Can J Fish Aquat Sci 57:380-390.

23. Balch GC, Evans RD, Welbourn P, Prairie R. 2000. Weight loss and net abnormalities of Hydropsyche betteni (caddisfly) larvae exposed to aqueous zinc. Environ Toxicol Chem 19:3036-3043.

24. American Public Health Association, American Water Works Association, and Water Environment Federation. 1998. Standard Methods for the Examination of Water and Wastewater, 20th ed. American Public Health Association, Washington, DC.

25. Sangpradub N, Giller PS. 1994. Gut morphology, feeding rate, and gut clearance in five species of caddis larvae. Hydrobiologia 287:215-223.
26. Croteau M-N, Hare L, Terrier A. 2001. Differences in Cd accumulation among species of the lake-dwelling biomonitor Chaoborus. Can J Fish Aquat Sci 58:1737-1746.

27. Wallace WG, Lee B-G, Luoma SN. 2003. The subcellular compartmentalization of $\mathrm{Cd}$ and $\mathrm{Zn}$ in two bivalves. I. The significance of metal-sensitive fractions (MSF) and biologically detoxified metal (BDM). Mar Ecol Prog Ser 249:183-197.

28. Ritterhoff J, Zauke G-P. 1998. Potential role of metal-binding proteins in cadmium detoxification in Themisto libellula (Mandt) and Themisto abyssorum Boeck from the Greenland Sea. Mar Environ Res 45:179-191.

29. Rainbow PS, Amiard-Triquet C, Amiard JC, Smith BD, Best SL, Nassiri Y, Langston WJ. 1999. Trace-meal uptake rates in crustaceans (amphipods and crabs) from coastal sites in NW Europe differentially enriched with trace metals. Mar Ecol Prog Ser 183: 189-203.

30. Evans RD, Balch GC, Evans HE, Welbourn PM. 2002. Simultaneous measurement of uptake and elimination of cadmium by caddisfly (Trichoptera: Hydropsychidae) larvae using stable isotope tracers. Environ Toxicol Chem 21:1032-1039.

31. Rouleau C, Block M, Tjälve H. 1998. Kinetics and body distribution of waterborne ${ }^{65} \mathrm{Zn}(\mathrm{II}),{ }^{109} \mathrm{Cd}(\mathrm{II}),{ }^{203} \mathrm{Hg}(\mathrm{II})$, and $\mathrm{CH}_{3}^{203}$ $\mathrm{Hg}(\mathrm{II})$ in phantom midge larvae (Chaoborus americanus) and effects of complexing agents. Environ Sci Technol 32:12301236.

32. Croteau M-N, Luoma SN, Topping BR, Lopez CB. 2004. Stable metal isotopes reveal copper accumulation and loss dynamics in the freshwater bivalve Corbicula. Environ Sci Technol 38:50025009.

33. Timmermans KR, Peeters W, Tonkes M. 1992. Cadmium, zinc, lead, and copper in Chironomus riparius (Meigen) larvae (Diptera, Chironomidae): Uptake and effects. Hydrobiologia 241: 119-134.

34. Wang W-X, Fisher NS. 1998. Accumulation of trace elements in a marine copepod. Limnol Oceanogr 43:273-283.

35. Croteau M-N, Hare L, Tessier A. 2002. Influence of temperature on $\mathrm{Cd}$ accumulation by species of the biomonitor Chaoborus. Limnol Oceanogr 47:505-514.

36. Roditi HA, Fisher NS. 1999. Rates and routes of trace element uptake in zebra mussels. Limnol Oceanogr 44:1730-1749.

37. Wang W-X, Fisher NS, Luoma SN. 1996. Kinetic determinations of trace element bioaccumulation in the mussel Mytilus edulis. Mar Ecol Prog Ser 140:91-113.

38. Jenkins KD, Mason AZ. 1988. Relationships between subcellular distributions of cadmium and perturbations in reproduction in the polychaete Neanthes arenaceodentata. Aquat Toxicol 12:229244.

39. Maroni G, Wise J, Young JE, Otto E. 2003. Metallothionein gene duplications and metal tolerance in natural populations of Drosophila melanogaster. Genetics 117:739-744.

40. Olsson P-E, Hogstrand C. 1987. Subcellular distribution and binding of cadmium to metallothionein in tissues of rainbow trout after exposure to ${ }^{109} \mathrm{Cd}$ in water. Environ Toxicol Chem 6:867874.

41. Darlington ST, Gower AM. 1990. Location of copper in larvae of Plectrocnemia conspersa (Curtis) (Trichoptera) exposed to elevated metals concentrations in a mine drainage stream. $\mathrm{Hy}$ drobiologia 196:91-100. 